Article

\title{
Functional and Preliminary Characterisation of Hydrocolloid from Tamarillo (Solanum betaceum Cav.) Puree
}

\section{Sri Puvanesvari Gannasin, Yogeshini Ramakrishnan, Noranizan Mohd. Adzahan and Kharidah Muhammad *}

Faculty of Food Science and Technology, Universiti Putra Malaysia, Serdang 43400, Selangor Darul Ehsan, Malaysia

* Author to whom correspondence should be addressed; E-Mail: kharidah@putra.upm.edu.my; Tel.: +603-8946-8394; Fax: +603-8942-3552.

Received: 31 March 2012; in revised form: 25 May 2012 / Accepted: 31 May 2012 /

Published: 5 June 2012

\begin{abstract}
Hydrocolloid from tamarillo (Solanum betaceum Cav.) puree was extracted using water and characterised for the first time. Proximate compositions of the extracted hydrocolloid were also determined. Functional characteristics such as water-holding capacity, oil-holding capacity, emulsifying activity, emulsion stability, foaming capacity and stability of the hydrocolloid were evaluated in comparison to that of commercial hydrocolloids. Its functional groups and degree of esterification were determined using Fourier Transform Infrared (FT-IR) spectroscopy. Monosaccharide profiling was done using reverse-phase high pressure liquid chromatography (RP-HPLC). Screening of various fruits for high hydrocolloid yield after water extraction resulted in tamarillo giving the highest yield. The yield on dry weight basis was $8.30 \%$. The hydrocolloid constituted of $0.83 \%$ starch, $21.18 \%$ protein and $66.48 \%$ dietary fibre with $49.47 \%$ degree of esterification and the monosaccharides identified were mannose, ribose, rhamnose, galacturonic acid, glucose, galactose, xylose and arabinose. Higher oil-holding capacity, emulsifying activity and emulsion stability compared to commercial hydrocolloids propose its possible application as a food emulsifier and bile acid binder. Foaming capacity of $32.19 \%$ and good foam stabilisation $(79.36 \%$ of initial foam volume after $2 \mathrm{~h}$ of foam formation) suggest its promising application in frothy beverages and other foam based food products. These findings suggest that water-extracted tamarillo hydrocolloid can be utilised as an alternative to low methoxyl pectin.
\end{abstract}


Keywords: tamarillo; hydrocolloid; extraction; functional; FT-IR; RP-HPLC

\section{Introduction}

Hydrocolloids refer to a range of polysaccharides and proteins that are widely used in the food, cosmetic and pharmaceutical industries. The food industry, in particular, has seen a large increase in the use of hydrocolloids in recent years to perform a number of functions, including thickening and gelling aqueous solutions, stabilising foams, emulsions and dispersions, inhibiting ice and sugar crystal formation and the controlled release of flavours [1-3]. This multitude of functions can be achieved by incorporating hydrocolloids at $1 \%$ concentration or less which can have a significant influence on the textural and organoleptic properties of food products $[3,4]$.

Hydrocolloids which are high molecular weight hydrophilic biopolymers include polysaccharides from various sources such as seaweeds, microorganisms, plants and animals. In addition, the unique protein gelatine is also classified as a hydrocolloid [1,3,5].

The world hydrocolloid market which is valued around USD 4.4 billion p.a. with a total volume of about 260,000 tonnes in 2000 reflects a remarkable demand for hydrocolloids which inevitably influences the price and security of supply [3]. Parallel with the increase in the hydrocolloid market demand, growing research interest to exploit some new raw materials as potential sources of food hydrocolloids can be observed. Hydrocolloids extracted from plants especially, have an advantage over those from microorganisms and animals because of their friendly image towards consumers.

Since vegetables consist predominantly of insoluble fibre fraction, fruits are of much interest among researchers to study the soluble fibre fraction which has good technological and health functionalities [6-10]. Preliminary comparative study of various tropical and sub-tropical fruits using the water extraction method indicated that tamarillo (Solanum betaceum Cav.), an undervalued fruit in Malaysia, gave the highest hydrocolloid yield.

Tamarillo or tree tomato is a subtropical fruit native to the Andes region of Peru, Chile, Ecuador, and Bolivia. It is also being cultivated in other countries, such as Argentina, Australia, Brazil, Colombia, Indonesia, Kenya, Malaysia (Cameron Highlands), New Zealand, Portugal and Venezuela [11-13]. Tamarillo types are best distinguished according to their peel and pulp colours. The type which is available in Malaysia is the egg-shaped, with thin reddish-brown skin and orange pulp, and dark red seed mucilage coating the seeds. To date, this cheap (USD 1/kg in Malaysia) and underutilised fruit remains unexplored except for its antioxidant profile [12,14,15]. Hence, this study is dedicated to investigate the possible exploitation of tamarillo as a food hydrocolloid source. Being extracted for the first time, important functional characteristics such as water-holding and oil-holding capacities, emulsifying activity, emulsion stability, foaming capacity and stability of the tamarillo hydrocolloid were studied in comparison to that of commercial hydrocolloids. In addition, the functional groups present in the tamarillo hydrocolloid was identified using Fourier Transform Infrared (FT-IR) spectroscopy. The monosaccharide composition of tamarillo hydrocolloid was also studied using reverse-phase high pressure liquid chromatography (RP-HPLC). These findings were expected to 
provide a basis for better understanding of this newly extracted hydrocolloid that might have a great importance in various food applications.

\section{Results and Discussion}

\subsection{Hydrocolloid Yield of Various Tropical and Sub-Tropical Fruits Using Water Extraction Method}

Screening of 15 fruits for high hydrocolloid yield (Y, \% dry weight) revealed that the tamarillo pulp fraction had the highest hydrocolloid content $(8.39 \%)$, followed by tamarillo puree $(8.30 \%)$, papaya (7.23\%), mango (6.62\%) and sapodilla (5.66\%) pulps, as shown in Table 1.

Table 1. Hydrocolloid yield (\% fresh and dry weight) of various tropical and sub-tropical fruits.

\begin{tabular}{|c|c|c|c|c|c|}
\hline Common name & Botanical name & Fraction & $\begin{array}{c}\text { Moisture content } \\
(\%) \\
\end{array}$ & $\begin{array}{c}\text { Yield, } Y_{f} \\
\text { (\% fresh weight) }\end{array}$ & $\begin{array}{c}\text { Yield, Y } \\
\text { (\% dry weight) }\end{array}$ \\
\hline \multirow{4}{*}{$\begin{array}{l}\text { Tamarillo } \\
\text { (buah cinta) }\end{array}$} & Solanum betaceum & Pulp & $85.82^{\mathrm{a}} \pm 0.13$ & $1.19^{\mathrm{a}} \pm 0.02$ & $8.39^{\mathrm{a}} \pm 0.03$ \\
\hline & Cav. & & & & \\
\hline & & Seed mucilage & $88.70^{b} \pm 0.30$ & $0.40^{\mathrm{bf}} \pm 0.08$ & $3.54^{b} \pm 0.16$ \\
\hline & & Puree & $85.78^{a} \pm 0.09$ & $1.18^{\mathrm{ac}} \pm 0.10$ & $8.30^{\mathrm{c}} \pm 0.07$ \\
\hline Papaya & Carica papaya & Pulp & $84.64^{c} \pm 0.04$ & $1.11^{\mathrm{acd}} \pm 0.06$ & $7.23^{\mathrm{d}} \pm 0.15$ \\
\hline Sapodilla (ciku) & Manilkara zapota & Pulp & $80.92^{d} \pm 0.06$ & $1.08^{\mathrm{cd}} \pm 0.11$ & $5.66^{\mathrm{e}} \pm 0.23$ \\
\hline Mango & Mangifera indica & Pulp & $84.28^{\mathrm{ce}} \pm 0.03$ & $1.04^{\mathrm{d}} \pm 0.13$ & $6.62^{\mathrm{f}} \pm 0.07$ \\
\hline Kiwifruit & Actinidia deliciosa & Pulp & $87.01^{\mathrm{f}} \pm 0.04$ & $0.90^{\mathrm{e}} \pm 0.04$ & $6.93^{\mathrm{g}} \pm 0.15$ \\
\hline $\begin{array}{l}\text { Mandarin } \\
\text { orange }\end{array}$ & Citrus reticulata & Peel & $75.20^{\mathrm{g}} \pm 0.27$ & $0.47^{\mathrm{b}} \pm 0.02$ & $1.90^{\mathrm{h}} \pm 0.10$ \\
\hline Garden tomato & $\begin{array}{l}\text { Lycopersicon } \\
\text { esculentum }\end{array}$ & $\begin{array}{l}\text { Whole without } \\
\text { seeds }\end{array}$ & $91.24^{\mathrm{h}} \pm 0.15$ & $0.42^{\mathrm{bf}} \pm 0.08$ & $4.79^{\mathrm{i}} \pm 0.08$ \\
\hline Pineapple & Ananas comosus & Pulp & $89.95^{\mathrm{i}} \pm 0.03$ & $0.40^{\mathrm{bf}} \pm 0.03$ & $3.98^{\mathrm{j}} \pm 0.11$ \\
\hline $\begin{array}{l}\text { Marian plum } \\
\text { (kundang) }\end{array}$ & Bouea macrophylla & Pulp & $84.13^{\mathrm{e}} \pm 0.15$ & $0.34^{\mathrm{f}} \pm 0.10$ & $2.14^{\mathrm{k}} \pm 0.03$ \\
\hline $\begin{array}{l}\text { Red dragon } \\
\text { fruit }\end{array}$ & $\begin{array}{l}\text { Hylocereus } \\
\text { polyrhizus }\end{array}$ & Pulp & $87.69^{\mathrm{j}} \pm 0.08$ & $0.33^{\mathrm{f}} \pm 0.11$ & $2.68^{1} \pm 0.07$ \\
\hline Guava & Psidium guajava & Whole without seeds & $91.29^{h} \pm 0.08$ & $0.20^{\mathrm{g}} \pm 0.02$ & $2.30^{\mathrm{m}} \pm 0.06$ \\
\hline $\begin{array}{l}\text { Water apple } \\
\text { (jambu air) }\end{array}$ & Syzygium aqueum & Whole & $92.50^{\mathrm{k}} \pm 0.03$ & $0.20^{\mathrm{g}} \pm 0.03$ & $2.67^{1} \pm 0.06$ \\
\hline Jackfruit & $\begin{array}{l}\text { Artocarpus } \\
\text { heterophyllus }\end{array}$ & Pulp & $77.92^{1} \pm 0.33$ & $0.20^{\mathrm{g}} \pm 0.05$ & $0.91^{\mathrm{n}} \pm 0.09$ \\
\hline Honeydew & Cucumis melo & Whole without seeds & $94.36^{\mathrm{m}} \pm 0.03$ & $0.20^{\mathrm{g}} \pm 0.02$ & $3.55^{b} \pm 0.23$ \\
\hline Red apple & Malus pumila & Whole without seeds & $83.56^{\mathrm{n}} \pm 0.23$ & $0.16^{\mathrm{g}} \pm 0.06$ & $0.97^{\circ} \pm 0.04$ \\
\hline Cupuassu & $\begin{array}{l}\text { Theobroma } \\
\text { grandiflorum }\end{array}$ & Pulp & NA & NA & $7.00^{\mathrm{g}} \pm \mathrm{NA}[16]^{*}$ \\
\hline Longan & Dimocarpus longan & Pulp & NA & NA & $4.46^{\mathrm{i}} \pm 0.09[17] *$ \\
\hline Gold kiwifruit & Actinidia chinensis & Whole & $80.99^{\mathrm{d}} \pm 0.14$ & NA & $6.69^{\mathrm{f}} \pm \mathrm{NA}[18]^{*}$ \\
\hline
\end{tabular}

Each value is expressed as mean \pm standard deviation $(n=3)$ of triplicate analysis. ${ }^{\text {a-o }}$ Means followed by different superscripts indicate significant differences $(p<0.05)$ within column by Tukey’s test. * Published data. 
Hydrocolloids from these fruit fractions appeared in a globular shape (Figure 1a) when immersed in chilled aqueous ethanol, except for tamarillo puree. Another type of hydrocolloid which has a continuous fibrilar network (Figure 1b) was observed when extraction was done with tamarillo seed mucilage, kiwifruit, dragon fruit pulp, cored apple, orange peel and other fruits that were screened.

Figure 1 shows the visual presence of globular and continuous fibrilar network hydrocolloids that were observed during hydrocolloid extraction from tamarillo pulp, seed mucilage and puree. The differences between pulp, seed mucilage and puree fractions in relation to the morphological parts of tamarillo fruit were described in Section 3.2. It can be noted that tamarillo puree fraction has both globular and continuous fibrilar network hydrocolloids (Figure 1c). Since it is not feasible and economical for the food industry to extract either the pulp or seed mucilage hydrocolloid of the fruit, the puree fraction (combination of pulp and seed mucilage fractions) was studied. It is worth highlighting here that water extracted hydrocolloid from tamarillo puree $\left(\mathrm{TH}_{\text {water }}\right)$ accounted for the highest yield compared to that of other fruits that were screened and previously studied [16-18] using water extraction method.

Figure 1. Visual presence of globular and continuous fibrilar network hydrocolloids (after precipitation in chilled aqueous ethanol) from tamarillo fruit fractions.

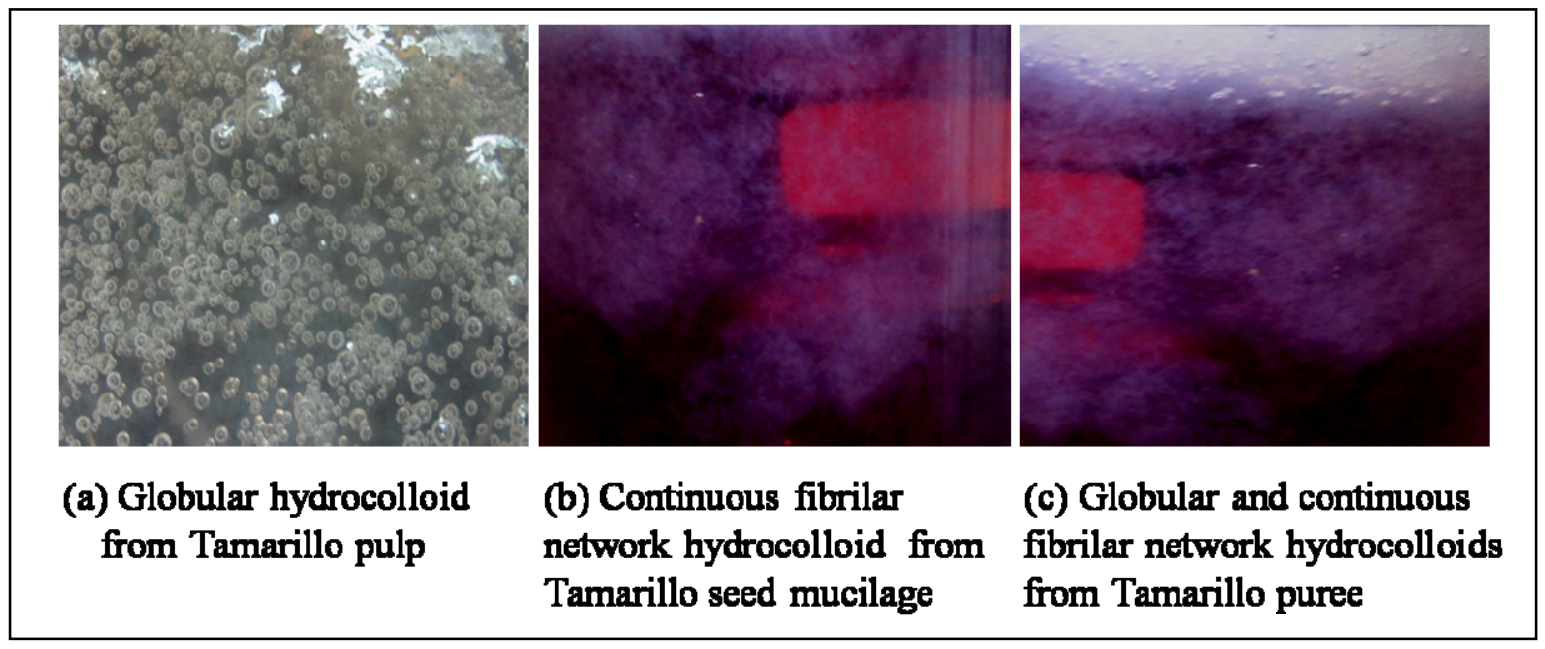

\subsection{Proximate Compositions of Tamarillo Hydrocolloid}

Table 2 shows the proximate compositions of $\mathrm{TH}_{\text {water }}$. It is interesting to note that the protein content was quite high $(21.18 \pm 0.06 \%)$ which might be contributed by the seed mucilage fraction in the tamarillo puree. A small amount of starch was also detected in $\mathrm{TH}_{\text {water }}$, besides the major component, dietary fibre, which accounted for $66.48 \pm 0.52 \%$. Since $\sim 90 \%$ of $\mathrm{TH}_{\text {water }}$ was made up of protein, starch and dietary fibre, the term hydrocolloid was used instead of polysaccharide. Protein and starch were purposely not removed from the extract by enzymatic treatment since these two components might contribute to good functional characteristics that are needed for various food applications. 
Table 2. Proximate compositions of tamarillo hydrocolloid extracted using water $\left(\mathrm{TH}_{\mathrm{water}}\right)$.

\begin{tabular}{lc}
\hline Component & Composition \\
\hline Moisture (\%) & $10.65 \pm 0.32$ \\
Dry matter (\%) & $89.35 \pm 0.32$ \\
Ash (\% dry weight) & $0.80 \pm 0.09$ \\
Protein (\% dry weight) & $21.18 \pm 0.06$ \\
Starch (\% dry weight) & $0.83 \pm 0.06$ \\
Dietary fibre by difference ${ }^{\text {a }}$ (\% dry weight) & $66.48 \pm 0.52$ \\
\hline
\end{tabular}

Each value is expressed as mean \pm standard deviation $(\mathrm{n}=3)$ of triplicate analysis; ${ }^{\text {a }}$ Dietary fibre by difference $=100 \%-($ Moisture + Ash + Protein + Starch $) \%$.

\subsection{Functional Properties of Tamarillo Hydrocolloid in Comparison to that of Commercial Hydrocolloids}

To date, there are no published research articles showing a comparison between the functional properties of commercial hydrocolloids from various sources. Therefore, this work is expected to help the food manufacturers especially in selecting the right hydrocolloid to be incorporated into food for specific functionalities.

\subsubsection{Water-Holding Capacity (WHC) and Oil-holding Capacity (OHC)}

As shown in Table 3, there is no significant difference between $\mathrm{WHC}$ of apple pectin and $\mathrm{TH}_{\text {water }}$ and likewise for $\mathrm{OHC}$.

Table 3. Water holding capacity (WHC) and oil holding capacity (OHC) of Tamarillo and commercial hydrocolloids.

\begin{tabular}{ccc}
\hline Type of hydrocolloid & WHC (g water/g dry sample) & OHC (g oil/g dry sample) \\
\hline $\mathrm{TH}_{\text {water }}$ & $5.82^{\mathrm{a}} \pm 0.75$ & $2.00^{\mathrm{ab}} \pm 0.07$ \\
Agar-agar & $7.99^{\mathrm{b}} \pm 0.80$ & $2.25^{\mathrm{b}} \pm 0.07$ \\
Apple pectin & $6.71^{\mathrm{ab}} \pm 0.52$ & $2.11^{\mathrm{ab}} \pm 0.17$ \\
Bovine gelatine & $0.00^{\mathrm{c}} \pm 0.00$ & $1.06^{\mathrm{cfg}} \pm 0.03$ \\
Carrageenan & $28.21^{\mathrm{d}} \pm 0.92$ & $1.31^{\mathrm{dh}} \pm 0.05$ \\
Citrus pectin & $1.38^{\mathrm{c}} \pm 0.06$ & $1.55^{\mathrm{de}} \pm 0.09$ \\
CMC & $0.00^{\mathrm{c}} \pm 0.00$ & $1.58^{\mathrm{e}} \pm 0.03$ \\
Gum arabic & $0.28^{\mathrm{c}} \pm 0.15$ & $1.00^{\mathrm{cf}} \pm 0.10$ \\
Karaya gum & $24.39^{\mathrm{e}} \pm 0.17$ & $1.12^{\mathrm{cfgh}} \pm 0.02$ \\
Sodium alginate & $0.00^{\mathrm{c}} \pm 0.00$ & $1.22^{\mathrm{fgh}} \pm 0.02$ \\
Wheat starch & $0.74^{\mathrm{c}} \pm 0.02$ & $0.92^{\mathrm{c}} \pm 0.03$ \\
Xanthan gum & $62.63^{\mathrm{f}} \pm 0.91$ & $1.28^{\mathrm{gh}} \pm 0.03$ \\
\hline
\end{tabular}

Each value is expressed as mean \pm standard deviation $(\mathrm{n}=3)$ of triplicate analysis; ${ }^{\mathrm{a}-\mathrm{h}}$ Means followed by different superscripts indicate significant differences $(p<0.05)$ within column by Tukey's HSD test.

It can be observed that $\mathrm{TH}_{\text {water }}$ demonstrated higher WHC compared to that of bovine gelatine, citrus pectin, carboxymethyl cellulose sodium salt (CMC), gum arabic, sodium alginate and wheat starch. In contrast, the WHC of $\mathrm{TH}_{\text {water }}$ was lower than that presented by xanthan gum, carrageenan and karaya 
gum. These findings suggest that xanthan gum, carrageenan and karaya gum are better at reducing syneresis and modifying the texture of foods. In addition, hydrocolloids with high WHC can be used as fat replacers in low-fat/calorie food formulations [19,20]. The $\mathrm{OHC}$ of $\mathrm{TH}_{\mathrm{water}}$ was higher than that shown by bovine gelatine, carrageenan, citrus pectin, $\mathrm{CMC}$, gum arabic, karaya gum, sodium alginate, wheat starch and xanthan gum suggesting the application of $\mathrm{TH}_{\text {water }}$ as a food emulsifier.

\subsubsection{Emulsifying Activity (EA) and Emulsion Stability (ES)}

Figure 2 shows the EA and ES of tamarillo and commercial hydrocolloids. It is interesting to note that $\mathrm{TH}_{\text {water }}$ demonstrated the highest EA $(84.74 \pm 0.46 \%)$ compared to all the commercial hydrocolloids studied. This finding was consistent with the $\mathrm{OHC}$ of $\mathrm{TH}_{\text {water }}$ that confirmed the possible application of $\mathrm{TH}_{\text {water }}$ as a plant based food emulsifier in stabilisation of high fat food products and emulsions.

Figure 2. Emulsifying activity (EA) and emulsion stability (ES) of tamarillo and commercial hydrocolloids.

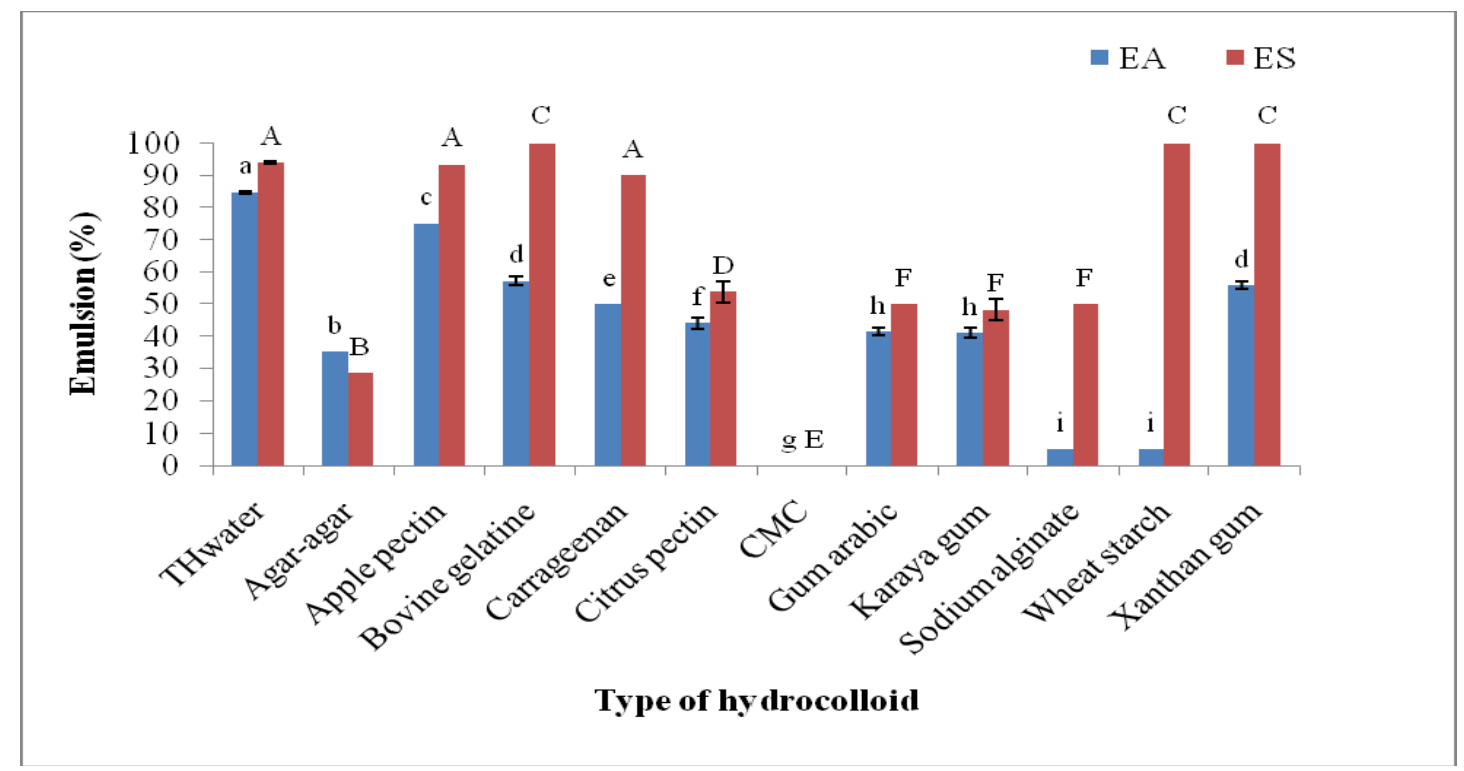

Each value is expressed as mean \pm standard deviation $(n=3)$ of triplicate analysis; ${ }^{a-i}$ Means followed by different superscript lowercase letters indicate significant differences $(p<0.05)$ between EA of hydrocolloids by Tukey's HSD test. ${ }^{\mathrm{A}-\mathrm{F}}$ Means followed by different superscript uppercase letters indicate significant differences $(p<0.05)$ between ES of hydrocolloids by Tukey's HSD test.

Moreover, the ES $(94 \pm 0.21 \%)$ of $\mathrm{TH}_{\text {water }}$ was higher than that of the widely used food emulsifier, gum arabic, which accounted for only $50 \pm 0.02 \%$ of ES. Besides the technological functionality, high EA and ES of $\mathrm{TH}_{\text {water }}$ were also very indicative of its ability to adsorb biliary acids which is one of the main mechanisms to reduce cholesterol level in blood [21]. 


\subsubsection{Foaming Capacity (FC) and Foaming Stability (FS)}

Foam is a colloid system with a gaseous phase stabilised in a continuous matrix to provide an aerated structure to a food product [22]. As expected, bovine gelatine showed the highest FC $\left(61.92 \pm 0.68 \%\right.$ ), followed by $\mathrm{TH}_{\text {water }}$ that presented $32.19 \pm 0.76 \%$ of FC (Figure 3 ).

Figure 3. Foaming capacity (FC) of tamarillo and commercial hydrocolloids at time, $\mathrm{t}=0$.

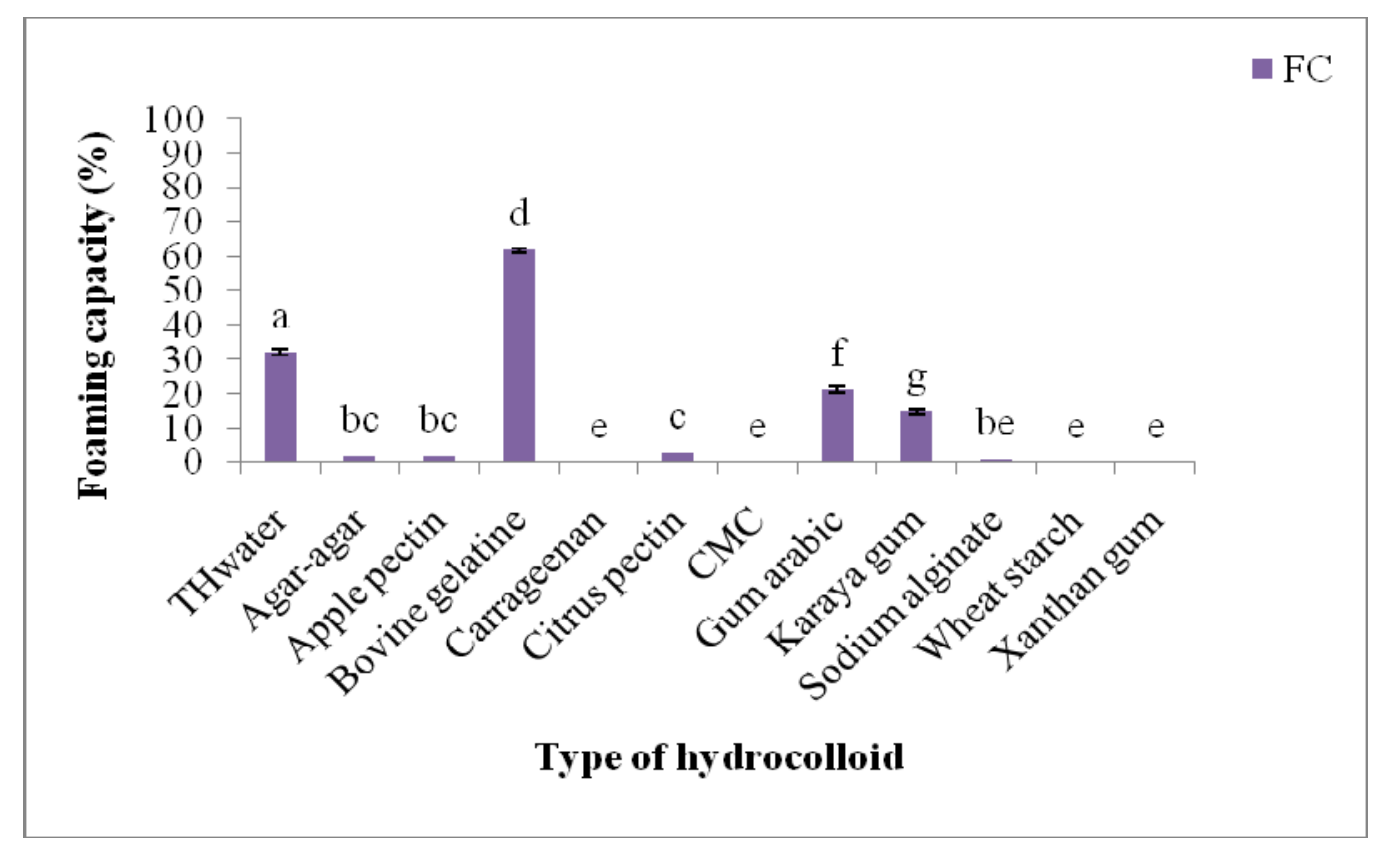

Each value is expressed as mean \pm standard deviation $(n=3)$ of triplicate analysis. ${ }^{a-g}$ Means followed by different superscript lowercase letters indicate significant differences $(p<0.05)$ between FC of hydrocolloids by Tukey's HSD test.

Although the $\mathrm{FC}$ of $\mathrm{TH}_{\text {water }}$ was lower than that of (animal based) bovine gelatine, $\mathrm{TH}_{\mathrm{water}}$ possessed a considerably high FC compared to other commercial hydrocolloids. This foaming characteristic of $\mathrm{TH}_{\text {water }}$ might be also be contributed by the protein present in the extract besides the major component, polysaccharides. Conversely, carrageenan, $\mathrm{CMC}$, wheat starch and xanthan have no FC. Agar-agar, sodium alginate, apple and citrus pectin showed a very low FC, in the range of 1 to $3 \%$ only.

Even though the FC of bovine gelatine was the highest, its FS reduced drastically from $90.36 \%$ ( $1 \mathrm{~min}$ after foam formation) to $11.01 \%$ ( $2 \mathrm{~h}$ after foam formation, Table 4$)$. In contrast, $\mathrm{TH}_{\text {water }}$ successfully maintained the foam volume through the $2 \mathrm{~h}(79.36 \%$ of initial volume) suggesting its application as foam stabiliser in frothy beverages such as cappuccino and beer. It can also be utilised in foam based food products such as mousses, marshmallows and meringues.

Karaya gum, apple and citrus pectin showed intermediate FS of $48.73 \%, 50 \%$ and $66.67 \%$, respectively after $2 \mathrm{~h}$ of foam formation. Gum arabic and sodium alginate showed a poorer FS. FS of carrageenan, CMC, wheat starch and xanthan gum were not determined since these hydrocolloids have no FC. 
Table 4. Foaming stability (\%) of tamarillo and commercial hydrocolloids.

\begin{tabular}{lcccccc}
\hline Hydrocolloids & \multicolumn{7}{c}{ Foaming stability (\%) at time, t (min) } \\
\cline { 2 - 7 } & $\mathbf{t}=\mathbf{1}$ & $\mathbf{t}=\mathbf{1 0}$ & $\mathbf{t}=\mathbf{3 0}$ & $\mathbf{t}=\mathbf{6 0}$ & $\mathbf{t}=\mathbf{9 0}$ & $\mathbf{t = 1 2 0}$ \\
\hline $\mathrm{TH}_{\text {water }}$ & $97.59^{\mathrm{aA}}$ & $91.96^{\mathrm{aB}}$ & $84.99^{\mathrm{aC}}$ & $81.51^{\mathrm{aD}}$ & $79.36^{\mathrm{aE}}$ & $79.36^{\mathrm{aE}}$ \\
Agar-agar & $100^{\mathrm{bA}}$ & $0^{\mathrm{bB}}$ & $0^{\mathrm{bB}}$ & $0^{\mathrm{bB}}$ & $0^{\mathrm{bB}}$ & $0^{\mathrm{bB}}$ \\
Apple pectin & $100^{\mathrm{bA}}$ & $100^{\mathrm{cA}}$ & $100^{\mathrm{cA}}$ & $50^{\mathrm{cB}}$ & $50^{\mathrm{cB}}$ & $50^{\mathrm{cB}}$ \\
Bovine gelatine & $90.36^{\mathrm{cA}}$ & $51.80^{\mathrm{dB}}$ & $31.57^{\mathrm{dC}}$ & $23.87^{\mathrm{dD}}$ & $19.77^{\mathrm{dE}}$ & $11.01^{\mathrm{dF}}$ \\
Carrageenan & n.d. & n.d. & n.d. & n.d. & n.d. & n.d. \\
Citrus pectin & $66.67^{\mathrm{dA}}$ & $66.67^{\mathrm{eA}}$ & $66.67^{\mathrm{eA}}$ & $66.67^{\mathrm{eA}}$ & $66.67^{\mathrm{eA}}$ & $66.67^{\mathrm{eA}}$ \\
CMC & n.d. & n.d. & n.d. & n.d. & n.d. & n.d. \\
Gum arabic & $90.46^{\mathrm{cA}}$ & $82.37^{\mathrm{fB}}$ & $66.77^{\mathrm{eC}}$ & $46.40^{\mathrm{fD}}$ & $28.69^{\mathrm{fE}}$ & $22.25^{\mathrm{fF}}$ \\
Karaya gum & $97.62^{\mathrm{aA}}$ & $85.79^{\mathrm{gB}}$ & $75.87^{\mathrm{fC}}$ & $75.87^{\mathrm{gC}}$ & $63.1^{\mathrm{gD}}$ & $48.73^{\mathrm{gE}}$ \\
Sodium alginate & $100^{\mathrm{bA}}$ & $100^{\mathrm{cA}}$ & $100^{\mathrm{cA}}$ & $50^{\mathrm{cB}}$ & $25^{\mathrm{hC}}$ & $12.5^{\mathrm{hD}}$ \\
Wheat starch & n.d. & n.d. & n.d. & n.d. & n.d. & n.d. \\
Xanthan gum & n.d. & n.d. & n.d. & n.d. & n.d. & n.d. \\
\hline
\end{tabular}

Each value is expressed as mean $(n=3)$ of triplicate analysis with standard deviation $<1$. n.d.: Not determined since foaming capacity of the hydrocolloid is $0 .^{\mathrm{a}-\mathrm{h}}$ Means followed by different superscript lowercase letters indicate significant differences $(p<0.05)$ within column by Tukey's test. ${ }^{\mathrm{A}-\mathrm{F}}$ Means followed by different superscript uppercase letters indicate significant differences $(p<0.05)$ within row by Tukey's test.

\subsection{Functional Groups and Degree of Esterification}

The Fourier Transform Infrared (FT-IR) spectra of $\mathrm{TH}_{\text {water }}$ and hydrocolloids that exhibited similar patterns are presented in Figure 4. A moderately intense absorption pattern between 1,300 and $800 \mathrm{~cm}^{-1}$ shows the 'fingerprint' region which is specific to each hydrocolloid. Based on this 'fingerprint' region, citrus and apple pectins were shortlisted from other commercial hydrocolloids that were compared (data not shown). It can be observed that $\mathrm{TH}_{\text {water }}$ had a very close 'fingerprint' region when compared with citrus pectin.

Figure 4. FT-IR spectra of tamarillo hydrocolloid $\left(\mathrm{TH}_{\mathrm{water}}\right)$, citrus and apple pectins.

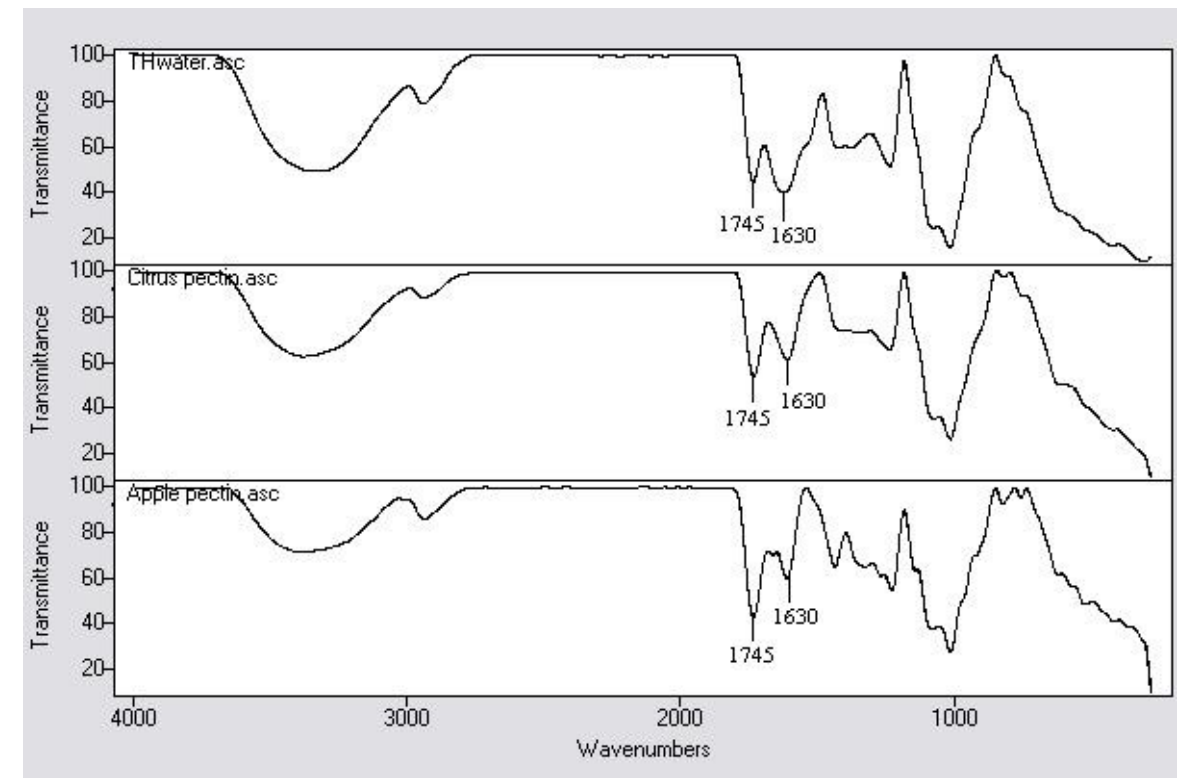


However, there was a clear difference that can be noted at bands at 1,745 and 1,630 $\mathrm{cm}^{-1}$. Citrus and apple pectins showed stronger absorptions at $1,745 \mathrm{~cm}^{-1}$ and weaker absorptions at $1,630 \mathrm{~cm}^{-1}$, whereas it was the reverse for $\mathrm{TH}_{\text {water. }}$ The absorption bands at 1,745 and $1,630 \mathrm{~cm}^{-1}$ correspond to the $\mathrm{C}=\mathrm{O}$ stretch of methyl esterified carbonyls and $\mathrm{COO}^{-}$asymmetric stretching of carboxylate anions, respectively. A weaker absorption at $1,745 \mathrm{~cm}^{-1}$ (ester carbonyl groups) coupled with a stronger absorption at $1,630 \mathrm{~cm}^{-1}$ (carboxylate groups) as demonstrated by $\mathrm{TH}_{\text {water }}$ suggest that $\mathrm{TH}_{\text {water }}$ might be a low methoxyl pectin. On contrary, the relative proportions of the absorption bands at 1,745 and $1,630 \mathrm{~cm}^{-1}$ as presented by citrus and apple pectins were indicative of high methoxyl pectins [23]. Common absorption bands observed were at $3,400 \mathrm{~cm}^{-1}$ which is attributed to $\mathrm{O}-\mathrm{H}$ stretching vibration, 2,930 $\mathrm{cm}^{-1}$ band due to $\mathrm{C}-\mathrm{H}$ stretching of $\mathrm{CH}_{2}$ groups and 1,400-1,435 $\mathrm{cm}^{-1}$ band that corresponded to $\mathrm{COO}^{-}$symmetric stretch of carboxylate anion [24,25].

These observations led to the quantitative measurement of degree of esterification (\% DE) of $\mathrm{TH}_{\text {water }}$, citrus and apple pectins (Table 5) as described in Section 3.6. Citrus and apple pectins can be categorised in the same group since their DE were almost similar although there was a slight significant difference. Citrus and apple pectins studied in this work were high methoxyl pectins since their DE was higher than 50\% [26] which correlates well with the stronger absorption observed at $1,745 \mathrm{~cm}^{-1}$ and weaker absorption at $1,630 \mathrm{~cm}^{-1}$. Conversely, the absorption bands at 1,745 and $1,630 \mathrm{~cm}^{-1}$ as showed by $\mathrm{TH}_{\text {water }}$ agreed well with the DE derived from the FT-IR spectrum. Based on these findings, it can be predicted that $\mathrm{TH}_{\text {water }}$ is a low methoxyl pectin since its DE was lower than $50 \%$ [26]. This propose the possible application of $\mathrm{TH}_{\text {water }}$ in reduced sugar food products and milk gels and desserts which have organic calcium ions since the gelation of low methoxyl pectin is governed by the interaction between pectin and calcium ions [27].

Table 5. Degree of esterification (DE) of tamarillo hydrocolloid $\left(\mathrm{TH}_{\mathrm{water}}\right)$, apple and citrus pectins measured using FT-IR spectroscopy.

\begin{tabular}{cr}
\hline Hydrocolloid & Degree of esterificati \\
\hline $\mathrm{TH}_{\text {water }}$ & $49.47^{\mathrm{a}} \pm 0.23$ \\
Citrus pectin & $68.00^{\mathrm{b}} \pm 0.19$ \\
Apple pectin & $69.64^{\mathrm{c}} \pm 0.26$ \\
\hline
\end{tabular}

Each value is expressed as mean \pm standard deviation $(n=3)$ of triplicate analysis; ${ }^{\text {acc }}$ Means followed by different superscripts indicate significant differences $(p<0.05)$ by Tukey's test.

\subsection{Monosaccharide Composition of Tamarillo Hydrocolloid}

High resolution simultaneous separation of 10 derivatised monosaccharides using RP-HPLC is shown in Figure 5. $\mathrm{TH}_{\text {water }}$ was predominantly constituted of galacturonic acid (GalU), glucose (Glc), galactose (Gal) and arabinose (Ara) in the order Gal $>$ Ara $>$ Glc $>$ GalU (Table 6).

Other neutral sugars such as mannose, ribose, rhamnose and xylose were found in trace quantities. Glucuronic acid and fucose were absent in $\mathrm{TH}_{\text {water. }}$ Four major constituents found in $\mathrm{TH}_{\text {water }}$ were in close agreement to that of longan pulp. The polysaccharide purified from longan pulp using water extraction method was composed of $33.7 \%$ Gal, 32.8\% Ara, 17.6\% Glc and 15.9\% GalU [28]. In addition, the monosaccharide profile of polysaccharide extracted from cupuassu pulp using water extraction method [16] was almost similar to that presented by $\mathrm{TH}_{\text {water }}$ and longan pulp. 
Figure 5. Chromatogram of PMP derivatives of monosaccharide standard and tamarillo hydrocolloid $\left(\mathrm{TH}_{\text {water }}\right)$.

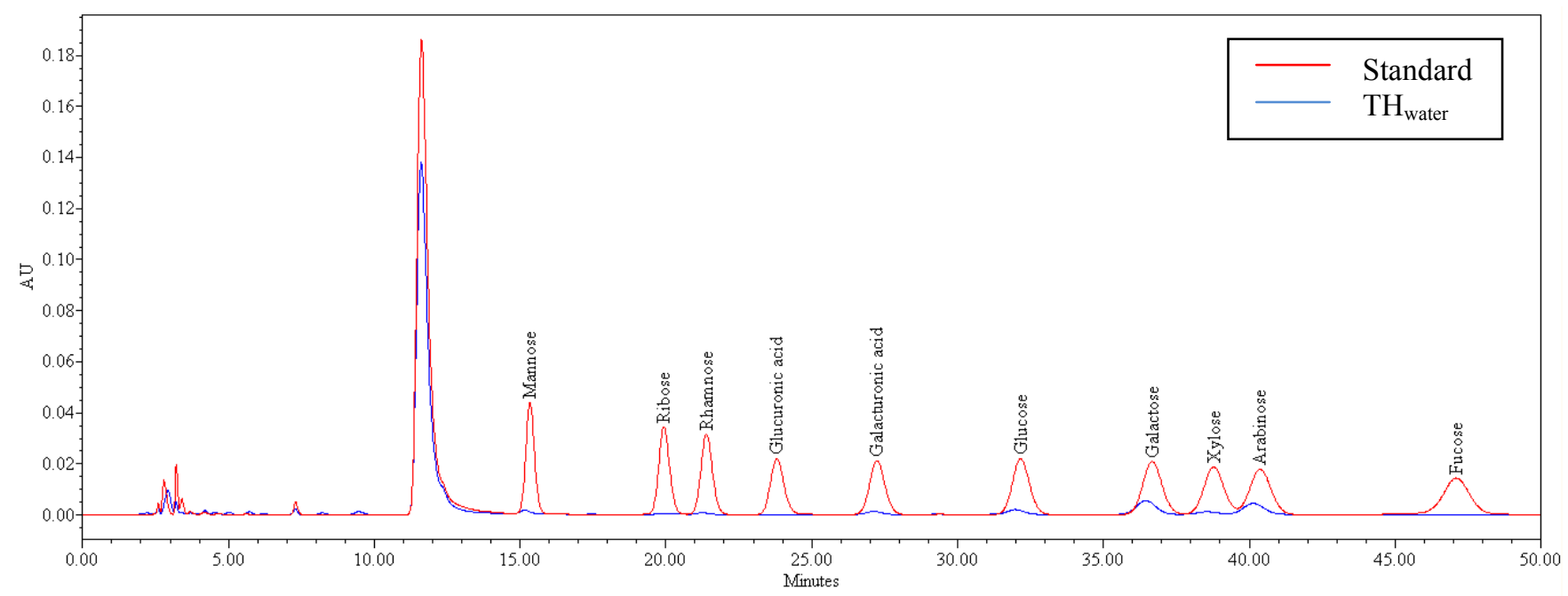

Table 6. Monosaccharide composition (mol \%) of hydrocolloid extracted from tamarillo puree $\left(\mathrm{TH}_{\mathrm{water}}\right)$.

\begin{tabular}{cc}
\hline Monosaccharide & ${\text { Composition }(\mathbf{m o l} \%)^{\mathbf{a}}}^{{ }^{\mathbf{b}}}$ \\
\hline Mannose & $\operatorname{Tr}^{\mathrm{b}}$ \\
Ribose & $\operatorname{tr}$ \\
Rhamnose & 0 \\
Glucuronic acid & $0.98 \pm 0.28$ \\
Galacturonic acid & $7.05 \pm 0.21$ \\
Glucose & $51.63 \pm 0.97$ \\
Galactose & $\operatorname{tr}$ \\
Xylose & $38.80 \pm 0.69$ \\
Arabinose & 0 \\
Fucose &
\end{tabular}

Each value is expressed as mean \pm standard deviation $(n=3)$ of triplicate analysis. ${ }^{a}$ mol $\%=$ (amount of individual monosaccharide/total amount of monosaccharide present in the sample) $\times 100$; ${ }^{\mathrm{b}}$ tr: Traces $<0.01 \mathrm{~mol} \%$.

The consistency of these findings suggest the high probability that the aforementioned four common monosaccharides origining from different polysaccharides are similarly fractionated when a water extraction method is used. In contrast, the presence of mannose and xylose in trace quantities might be due to poor extractability of mannose- and xylose-containing polysaccharides using the water extraction procedure. The poor extractability might be explained by the fact that xylose and mannose, being the major constituents of hemicelluloses, were extremely stable to the water extraction method. This is due to the strong bonds between cellulose and hemicellulose that cause difficulties in cleavage, even by treatment with strong acids [29]. However, hemicellulose constituents (xylose and mannose) were more extractable when strong alkali $(2 \mathrm{M}$ or $4 \mathrm{M} \mathrm{NaOH})$ were used [30]. Therefore, the extraction method plays a crucial role in achieving the right targeted monosaccharide profile that influences the functional properties of the extracted hydrocolloid. 
From the monosaccharide profile, functional groups and DE findings, $\mathrm{TH}_{\mathrm{water}}$ shows a resemblance to pectic polysaccharide.

\section{Experimental}

\subsection{Materials}

For each batch of analysis, fresh tamarillos with maturity stage between 21-24 weeks were purchased from five different growers in the Cameron Highlands, Malaysia. To get a representative sample, fruits purchased from different growers were well mixed and selected for uniformity of ripeness, size, skin colour and free of defects. Other fruits (apple, mandarin orange, red dragon fruit, kiwifruit, marian plum, garden tomato, guava, water apple, jackfruit, pineapple, honeydew, mango, papaya and sapodilla) for screening purpose were purchased from fruit stalls in Selangor, Malaysia.

Undenatured ethanol (95\%) was purchased from HmbG Chemicals (Hamburg, Germany). All reagents used for proximate analysis were of analytical grade. Agar-agar, bovine gelatine, carboxymethyl cellulose sodium salt (CMC), carrageenan, gum arabic, sodium alginate and xanthan gum were purchased from R\&M Chemicals (Essex, UK). Gum karaya and pectin from citrus peel (galacturonic acid $\geq 74.0 \%$ ) were purchased from Sigma-Aldrich (St. Louis, MO, USA and Copenhagen, Denmark), respectively. Starch from wheat and pectin from apples (degree of esterification, 70-75\%) were purchased from Fluka (Steinheim, Germany and Buchs, Switzerland), respectively. Monosaccharide standards and HPLC grade chemicals used for monosaccharide profiling analysis were purchased from Sigma-Aldrich and Merck (Darmstadt, Germany), respectively.

\subsection{Sample Preparation for Hydrocolloid Extraction}

Edible fractions of 13 fresh fruits and orange peel were homogenised with increasing speed repeatedly (4 × $1 \mathrm{~min}$ ) using a Waring laboratory blender (MS 153-5, Torrington, CT, USA). Although orange peel (raw material for commercial citrus pectin) is non edible, it was used for comparison study in hydrocolloid yield screening. Preparation of three fractions (pulp, seed mucilage and puree) of fresh tamarillo fruits was as described in Figure 6. Samples were packed in aluminium pouches and stored frozen $\left(-18^{\circ} \mathrm{C}\right)$ until analysis.

\subsection{Screening of Various Fruits for High Hydrocolloid Yield}

Fifteen tropical and subtropical fruits were screened for high hydrocolloid yield using the water extraction method as recommended by Yuliarti et al. [18] with some modifications. Homogenised fresh sample was extracted using distilled water at $50{ }^{\circ} \mathrm{C}$ for 30 min using 1:4 (w:v) sample to water ratio in shaking water bath. Extraction conditions were set based on optimum conditions described by Yuliarti et al. [18] and preliminary studies. The extract was centrifuged (3,300 g, $20 \mathrm{~min})$ and the supernatant was decanted. Water at $50{ }^{\circ} \mathrm{C}$ was added to the pellet in the ratio of $1: 1$ (w:v) to extract any remaining hydrocolloid, and centrifuged again as before. 
Figure 6. Preparation of pulp, seed mucilage and puree fractions from fresh Tamarillo fruits.

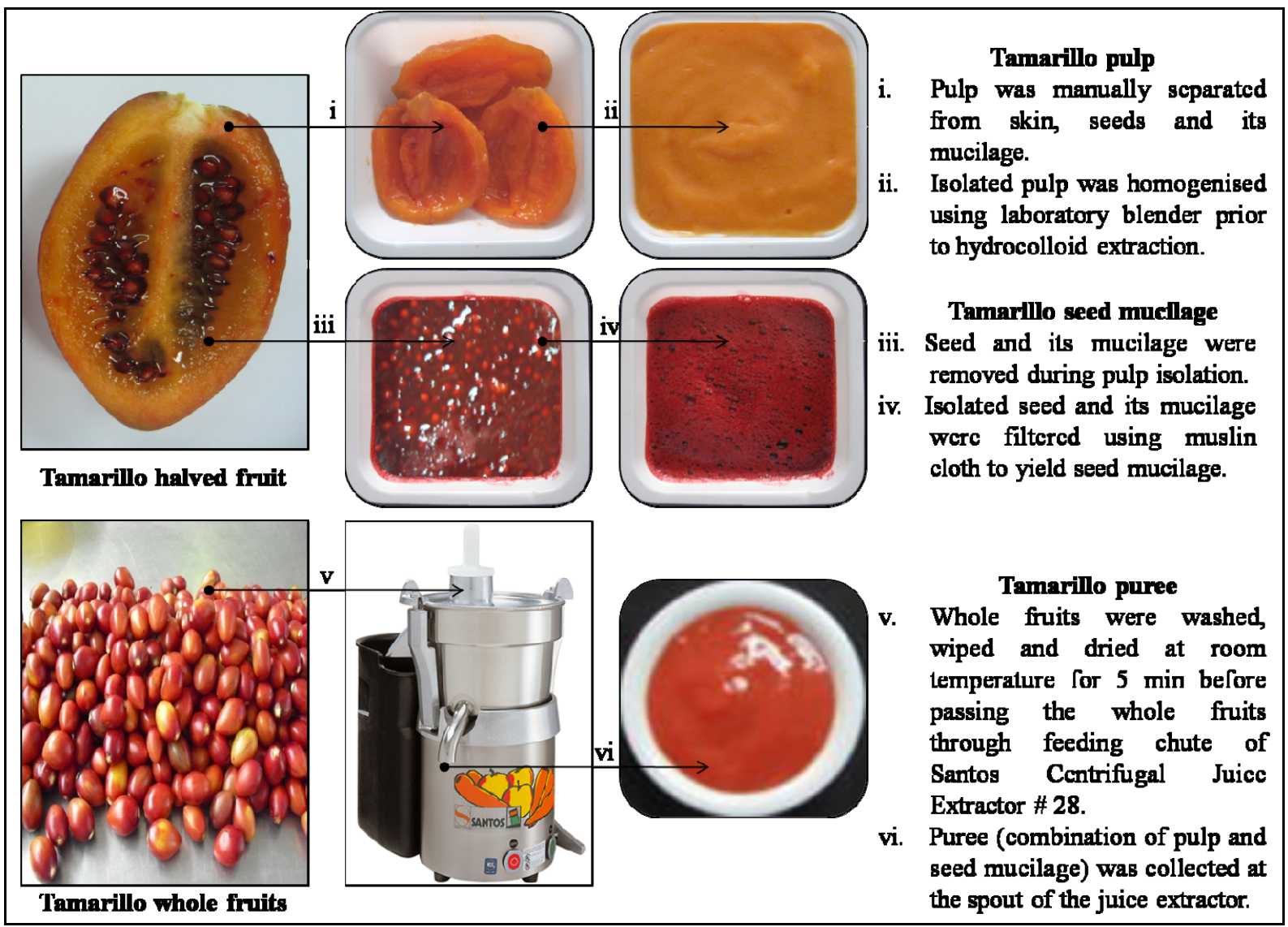

Undenatured ethanol (95\%) was added to the combined supernatants, the mixture was stirred and kept at $4{ }^{\circ} \mathrm{C}$ for $4 \mathrm{~h}$ to facilitate hydrocolloid precipitation. The mixture was centrifuged $(3,300 \mathrm{~g}$, $10 \mathrm{~min}$ ) and the supernatant was discarded. The pellet was washed twice with $95 \%$ undenatured ethanol $(1: 1 ; \mathrm{w}: \mathrm{v})$ and centrifuged again. The final pellet was placed on petri dish and oven-dried (Memmert, Schwabach, Germany) at $50{ }^{\circ} \mathrm{C}$ for $12 \mathrm{~h}$ until a constant weight was achieved. The dried pellet was then weighed for hydrocolloid yield calculation. Pulverisation of dried hydrocolloid using a pulverisette 14 variable speed rotor mill (Fritsch $\mathrm{GmbH}$, Oberstein, Germany) was performed only for the fruit fractions that demonstrated highest yield and good feasibility of study. The selected dried hydrocolloid was passed through a $200 \mu \mathrm{m}$ sieve (Fritsch $\mathrm{GmbH}$ ), packed and stored at cool and dry conditions until further characterisation.

Hydrocolloid yield on fresh $\left(\mathrm{Y}_{\mathrm{f}}\right)$ and dry $(\mathrm{Y})$ weight basis were calculated using equations (1) and (2), respectively:

$$
\begin{gathered}
\left.\mathrm{Y}_{\mathrm{f}}(\%)=100 \text { [weight of dried hydrocolloid }(\mathrm{g}) / \text { weight of fresh sample }(\mathrm{g})\right] \\
\mathrm{Y}(\%)=100 \mathrm{Y}_{\mathrm{f}} /(100 \text {-moisture content })
\end{gathered}
$$

Since $\mathrm{Y}$ allows comparison with that of reported in literatures, the moisture content of fruits to be screened was determined prior to $\mathrm{Y}$ calculation. Fruit fraction that demonstrated the highest $\mathrm{Y}$ was used for the subsequent studies and thus tamarillo puree was selected. Water extracted, dried and pulverised tamarillo hydrocolloid is identified as $\mathrm{TH}_{\text {water }}$ thereafter. 


\subsection{Proximate Analyses of Tamarillo Hydrocolloid}

Moisture content and dry matter were determined according to AOAC Method 934.01 [31]. Ash was analysed gravimetrically by incineration of samples in a muffle furnace for $2 \mathrm{~h}$ at $900{ }^{\circ} \mathrm{C}$. The protein content estimated as \% nitrogen $\times 6.25$ (conversion factor) was determined with the Kjeldahl method on a Kjeltec ${ }^{\mathrm{TM}} 8400$ Analyzer unit (FOSS-Tecator AB, Hoganas, Sweden) which is consistent with AOAC method 978.04 [31]. Total starch content was determined using Megazyme Total Starch Assay procedure which is based on AOAC Method 996.11 [31]. Dietary fibre was calculated by difference using the following equation:

$$
\text { Dietary fibre }(\%)=100 \%-(\text { Moisture }+ \text { Ash }+ \text { Protein }+ \text { Starch }) \%
$$

\subsection{Functional Characterisation of Tamarillo Hydrocolloid in Comparison to that of}

\section{Commercial Hydrocolloids}

\subsubsection{Water-holding Capacity (WHC) and Oil-holding Capacity (OHC)}

WHC and OHC were determined according to Robertson et al. [32] with some modifications. Distilled water or commercial olive oil $(25 \mathrm{~mL})$ were added to $250 \mathrm{mg}$ of dry sample, stirred and left at room temperature for $1 \mathrm{~h}$. After centrifugation, the residue was weighed. The WHC was expressed as $\mathrm{g}$ of water held per $\mathrm{g}$ of sample, while the $\mathrm{OHC}$ was expressed as $\mathrm{g}$ of oil held per $\mathrm{g}$ of sample.

\subsubsection{Emulsifying Activity (EA) and Emulsion Stability (ES)}

EA and ES were evaluated according to Chau et al. [33] with some modifications. A DIAX 900 Heidolph homogeniser (Schwabach, Germany) was used to homogenise a 2\% (w/v) sample suspension in water at 11,000 rpm for $30 \mathrm{~s}$. Sunflower oil $(100 \mathrm{~mL})$ was then added and homogenised for another $1 \mathrm{~min}$. The emulsions were centrifuged in $15 \mathrm{~mL}$ graduated centrifuge tubes at 1,200 g for $5 \mathrm{~min}$, and the volume of the emulsion left was measured. To determine the ES, emulsions prepared by the above procedures were heated at $80{ }^{\circ} \mathrm{C}$ for $30 \mathrm{~min}$ in an oven, cooled to room temperature, and centrifuged at $1,200 \mathrm{~g}$ for $5 \mathrm{~min}$. EA and ES were calculated using the following equations:

$$
\begin{gathered}
\mathrm{EA}=\frac{\text { Volume of emulsified layer }(\mathrm{mL})}{\text { Volume of whole layer in the centrifuge tube }(\mathrm{mL})} \times 100 \\
\mathrm{ES}=\frac{\text { Volume of remaining emulsified layer }(\mathrm{mL})}{\text { Original emulsion volume }(\mathrm{mL})} \times 100
\end{gathered}
$$

\subsubsection{Foaming capacity (FC) and Foaming Stability (FS)}

FC and FS were determined according to the method described by Coffman and Garcia [34]. One gram of sample was mixed with $100 \mathrm{~mL}$ of distilled water and the suspension was homogenised vigorously at 13,000 rpm for 5 min using a DIAX 900 Heidolph homogeniser (Schwabach, Germany). The homogenised suspension was immediately transferred to a $250 \mathrm{~mL}$ graduated cylinder and the 
foam volume was measured. Foam volume changes were recorded at intervals of 1, 10, 30, 60, 90 and $120 \mathrm{~min}$. FC and FS were calculated using the following equations:

$$
\begin{gathered}
\mathrm{FC}(\%)=\frac{(\text { Volume after homogenisation }- \text { Volume before homogenisation }) \mathrm{mL}}{(\text { Volume before homogenisation }) \mathrm{mL}} \times 100 \\
\mathrm{FS}(\%)=\frac{[\text { Foam volume after time }(\mathrm{t})] \mathrm{mL}}{(\text { Initial foam volume } \mathrm{mL}} \times 100
\end{gathered}
$$

\subsection{Functional Groups and Degree of Esterification Determination Using FT-IR Spectroscopy}

Samples were redried and stored in desiccators prior to FT-IR analysis to avoid shifts in the spectra because of interference from moisture particles. FT-IR spectra were recorded using a universal ATR accessory with diamond/KRS-5 as the contact crystal on a Perkin Elmer Spectrum 100 FT-IR spectrophotometer with CsI detector (Shelton, CT, USA). The spectra were recorded at the absorbance mode from 4,000 to $400 \mathrm{~cm}^{-1}$ (mid infrared region) at the resolution of $4 \mathrm{~cm}^{-1}$ and 128 scans were co-added to obtain a high signal-to-noise ratio. At least duplicate spectra readings for each sample were performed. Degree of esterification (DE) was measured for pectin and pectin-like samples. Since $\mathrm{DE}$ is defined as (number of esterified carboxylic groups/number of total carboxylic groups) $\times 100$, it is inferred that the ratio of the area of the band at $1,745 \mathrm{~cm}^{-1}$ (corresponding to the number of esterified carboxylic groups) over the sum of the areas of the bands at $1,745 \mathrm{~cm}^{-1}$ and $1,630 \mathrm{~cm}^{-1}$ (corresponding to the number of total carboxylic groups) should be proportional to the DE, i.e., $\mathrm{DE}=\mathrm{A} 1745 /(\mathrm{A} 1745+\mathrm{A} 1630)[24,25]$. The areas of interest were measured using OMNIC software version 8.0 (Thermo Nicolet Corp., Madison, WI, USA).

\subsection{Monosaccharide Profiling Using HPLC}

Monosaccharide standard solution was prepared as described by $\mathrm{Lv}$ et al. [35]. $\mathrm{TH}_{\mathrm{water}}$ was hydrolysed to monomers with trifluoroacetic acid (TFA) prior to derivatisation with 1-phenyl-3methyl-5-pyrazolone (PMP). The hydrolysis procedure described by Dai et al. [36] was carried out with a modification whereby the volume of all chemicals and sample solution needed for hydrolysis process was increased by $100 \times$, i.e., $10 \mathrm{~mL}$ was used instead of $100 \mu \mathrm{L}$. Derivatisation of monosaccharides with PMP [36] was done with the aforementioned modification until the step neutralisation with $0.3 \mathrm{M}$ hydrochloric acid. Then, $300 \mu \mathrm{L}$ of the resultant solution was evaporated to dryness using rotary evaporator and proceeded with liquid-liquid separation method [36].

Ten monosaccharides (glucose, galactose, arabinose, xylose, mannose, rhamnose, fucose, ribose, glucuronic acid and galacturonic acid) were separated using ZORBAX Eclipse Plus-C18 HPLC column (250 mm length, $4.6 \mathrm{~mm}$ internal diameter and $5 \mu \mathrm{m}$ particle size, Agilent Technologies, Santa Clara, CA, USA). A Waters e2695 HPLC equipped with a Waters 2489 UV/Vis detector was used. The HPLC conditions and mobile phase composition were as described by Dai et al. [36]. The data were collected using an Empower2 software (Waters, Milford, MA, USA). The concentration of monosaccharides identified in $\mathrm{TH}_{\text {water }}$ were calculated by comparing their integration values of peak area to a calibrated standard curve. 


\subsection{Statistical Analysis}

The statistical model was a one-way analysis of variance (ANOVA) for comparison of moisture content, extraction yield, WHC, OHC, EA, ES, FC and DE means. Twelve one-way ANOVA were performed to evaluate the significant differences between FS of different hydrocolloids. Six one-way ANOVA were carried out to determine the effect of time on FS of each hydrocolloid. Statistical analyses were carried out using Statistical Package for Social Science for Window, version 19.0 (SPSS Institute Inc., Cary, NC, USA). Treatment means were considered significantly different at $p<0.05$ and whenever applicable, means were separated by Tukey's HSD post hoc test.

\section{Conclusions}

Screening of various tropical and subtropical fruits for high hydrocolloid yield revealed that tamarillo can be a potential source of food hydrocolloid. A water extraction method was chosen since the method is safe for consumers and feasible for industrial scale-up. The hydrocolloid extracted from tamarillo puree consisted of $66.48 \%$ dietary fibre, $21.18 \%$ protein and $0.83 \%$ starch. The degree of esterification derived from FT-IR spectrum was $49.47 \%$. The monosaccharides identified were mannose, ribose, rhamnose, galacturonic acid, glucose, galactose, xylose and arabinose. Good oil-holding capacity (2.11g oil/g dry sample), emulsifying activity (84.74\%) and emulsion stability (94\%) propose its possible application as a plant based food emulsifier. Besides that, it demonstrated a foaming capacity of 32.19\% which is unique for a plant derived hydrocolloid. Interestingly, it showed better foam stabilisation (79.36\% of initial foam volume) characteristics than bovine gelatine (11.01\%) through 2 hours from the formation of the foam. These findings suggest that water extracted tamarillo hydrocolloid can be utilised as a low methoxyl pectin in reduced sugar products, milk gels and desserts. Ongoing works include extraction using different methods, and rheological and structural characterisations of other hydrocolloids from tamarillo to evaluate their potential as functional ingredients in food products.

\section{Acknowledgments}

We gratefully acknowledge the financial support received from Universiti Putra Malaysia Research Grant No. 02-01-11-1139 RU.

\section{References and Notes}

1. Dickinson, E. Hydrocolloids at interfaces and the influence on the properties of dispersed systems. Food Hydrocolloid. 2003, 17, 25-39.

2. Harris, P.J.; Smith, B.G. Plant cell walls and cell-wall polysaccharides: Structures, properties and uses in food products. Int. J. Food Sci. Technol. 2006, 41, 129-143.

3. Williams, P.A.; Phillips, G.O. Introduction to food hydrocolloids. In Handbook of Hydrocolloids; Phillips, G.O, Williams, P.A., Eds.; Woodhead Publishing Ltd: Cambridge, UK, 2000; pp. 1-19.

4. Walter, R.H. Classifications. In Polysaccharide Dispersions; Academic Press: New York, NY, USA, 1997; pp. 157-180.

5. Funami, T. Next target for food hydrocolloid studies: Texture design of foods using hydrocolloid technology. Food Hydrocolloid. 2011, 25, 1904-1914. 
6. Grigelmo-Miguel, N.; Gorinstein, S.; Martín-Belloso, O. Characterisation of peach dietary fibre concentrate as a food ingredient. Food Chem. 1999, 65, 175-181.

7. Grigelmo-Miguel, N.; Martín-Belloso, O. Influence of fruit dietary fibre addition on physical and sensorial properties of strawberry jams. J. Food Eng. 1999, 41, 13-21.

8. Kumar, A.; Chauhan, G.S. Extraction and characterization of pectin from apple pomace and its evaluation as lipase (steapsin) inhibitor. Carbohyd. Polym. 2010, 82, 454-459.

9. Sanchez-Alonso, I.; Borderias, A.J. Technological effect of red grape antioxidant dietary fibre added to minced fish muscle. Int. J. Food Sci. Technol. 2008, 43, 1009-1018.

10. Zhong, K.; Wang, Q.; He, Y.; He, X. Evaluation of radicals scavenging, immunity-modulatory and antitumor activities of longan polysaccharides with ultrasonic extraction on in S180 tumor mice models. Int. J. Biol. Macromol. 2010, 47, 356-360.

11. Acosta-Quezada, P.G.; Martínez-Laborde, J.B.; Prohens, J. Variation among tree tomato (Solanum betaceum Cav.) accessions from different cultivar groups: Implications for conservation of genetic resources and breeding. Genet. Resour. Crop Evol. 2010, doi:10.1007/s10722-010-9634-9.

12. De Rosso, V.V.; Mercadante, A.Z. HPLC-PDA-MS/MS of anthocyanins and carotenoids from Dovyalis and Tamarillo fruits. J. Agric. Food Chem. 2007, 55, 9135-9141.

13. Ordonez, R.M.; Vattuone, M.A.; Isla, M.I. Changes in carbohydrate content and related enzyme activity during Cyphomandra betaceae (Cav.) Sendtn. fruit maturation. Postharvest Biol. Tec. 2005, 35, 293-301.

14. Mertz, C.; Gancel, A.-L.; Gunata, Z.; Alter, P.; Dhuique-Mayer, C.; Vaillant, F.; Perez, A.M.; Ruales, J.; Brat, P. Phenolic compounds, carotenoids and antioxidant activity of three tropical fruits. J. Food Compos. Anal. 2009, 22, 381-387.

15. Vasco, C.; Ruales, J.; Kamal-Eldin, A. Total phenolic compounds and antioxidant capacities of major fruits from Ecuador. Food Chem. 2008, 111, 816-823.

16. Vriesmann, L.C.; de Oliveira Petkowicz, C.L. Polysaccharides from the pulp of cupuassu (Theobroma grandiflorum): Structural characterization of a pectic fraction. Carbohyd. Polym. 2009, 77, 72-79.

17. Zhong, K.; Wang, Q. Optimization of ultrasonic extraction of polysaccharides from dried longan pulp using response surface methodology. Carbohyd. Polym. 2010, 80, 19-25.

18. Yuliarti, O.; Goh, K.; Matia-Merino, L.; Mawson, J.; Drummond, L.; Brennan, C.S. Effect of extraction techniques and conditions on the physicochemical properties of the water soluble polysaccharides from gold kiwifruit (Actinidia chinensis). Int. J. Food Sci. Technol. 2008, 43, $2268-2277$.

19. Brewer, M.S. Reducing the fat content in ground beef without sacrificing quality: A review. Meat Sci. 2012, 91, 385-395.

20. Sandrou, D.K.; Arvanitoyannis, I.S. Low-fat/calorie foods: Current state and perspectives. Crit. Rev. Food Sci. 2010, 40, 427-447.

21. Alfredo, V.-O.; Gabriel, R.-R.; Luis, C.G.; David, B.A. Physicochemical properties of a fibrous fraction from chia (Salvia hispanica L.). LTW-Food Sci. Technol. 2009, 42, 168-173.

22. Naji, S.; Razavi, S.M.A.; Karazhiyan, H. Effect of thermal treatments on functional properties of cress seed (Lepidium sativum) and xanthan gums: A comparative study. Food Hydrocolloid. 2012, $28,75-81$. 
23. Liu, L.; Cao, J.; Huang, J.; Cai, Y.; Yao, J. Extraction of pectins with different degrees of esterification from mulberry branch bark. Bioresource Technol. 2010, 101, 3268-3273.

24. Chatjigakis, A.K.; Pappas, C.; Proxenia, N.; Kalantzi, O.; Rodis, P.; Polissiou, M. FT-IR spectroscopic determination of the degree of esterification of cell wall pectins from stored peaches and correlation to textural changes. Carbohyd. Polym. 1998, 37, 395-408.

25. Manrique, G.D.; Lajolo, F.M. FT-IR spectroscopy as a tool for measuring degree of methyl esterification in pectins isolated from ripening papaya fruit. Postharvest Biol. Technol. 2002, 25, 99-107.

26. Thakur, B.R.; Singh, R.K.; Handa, A.K. Chemistry and uses of pectin - a review. Crit. Rev. Food Sci. 1997, 37, 47-73.

27. May, C.D. Pectins. In Handbook of Hydrocolloids; Phillips, G.O., Williams, P.A., Eds.; Woodhead Publishing Ltd: Cambridge, UK, 2000; pp. 169-188.

28. Yang, B.; Jiang, Y.; Zhao, M.; Chen, F.; Wanga, R.; Chen, Y.; Zhang, D. Structural characterisation of polysaccharides purified from longan (Dimocarpus longan Lour.) fruit pericarp. Food Chem. 2009, 115, 609-614.

29. Ramirez-Truquea, C.; Esquivela, P.; Carleb, R. Neutral sugar profile of cell wall polysaccharides of pitaya (Hylocereus sp.) fruits. Carbohyd. Polym. 2011, 83, 1134-1138.

30. Cordenunsi, B.R.; Shiga, T.M.; Lajolo, F. Non-starch polysaccharide composition of two cultivars of banana (Musa acuminata L.: Cvs Mysore and Nanicao). Carbohyd. Polym. 2008, 71, 26-31.

31. AOAC. Official Methods of Analysis, 18th ed.; Horwitz, W., Latimer, G.W., Jr., Eds.; AOAC International: Gaithersburg, MD, USA, 2005.

32. Robertson, J.A.; de Monredon, F.D.; Dysseler, P.; Guillon, F.; Amado, R.; Thibault, J.F. Hydration properties of dietary fiber and resistant starch: A European collaborative study. LTW-Food Sci. Technol. 2000, 33, 72-79.

33. Chau, C.F.; Cheung, P.C.K.; Wong, Y.S. Functional properties of protein concentrate from three Chinese indigenous legume seeds. J. Agric. Food Chem. 1997, 45, 2500-2503.

34. Coffman, C.W.; Garcia, V.V. Functional properties and amino acid content of a protein isolate from mung bean flour. J. Food Technol. 1977, 12, 473-484.

35. Lv, Y.; Yang, X.; Zhao, Y.; Ruan, Y.; Ying, Y.; Wang, Z. Separation and quantification of component monosaccharides of the tea polysaccharides from Gynostemma pentaphyllum by HPLC with indirect UV detection. Food Chem. 2009, 112, 742-746.

36. Dai, J.; Wu, Y.; Chen, S.W.; Zhu, S.; Yin, H.P.; Wang, M.; Tang, J. Sugar compositional determination of polysaccharides from Dunaliella salina by modified RP-HPLC method of precolumn derivatization with 1-phenyl-3-methyl-5-pyrazolone. Carbohyd. Polym. 2010, 82, 629-635.

Sample Availability: Samples of tamarillo are available from the authors.

(C) 2012 by the authors; licensee MDPI, Basel, Switzerland. This article is an open access article distributed under the terms and conditions of the Creative Commons Attribution license (http://creativecommons.org/licenses/by/3.0/). 